\title{
STRATEGIES FOR THE IMPROVEMENT OF FRUIT SET IN VITIS VINIFERA L. CV. 'CARMÉNÈRE' THROUGH DIFFERENT FOLIAR BIOSTIMULANTS IN TWO DIFFERENT LOCATIONS
}

\author{
ESTRATÉGIAS PARA A MELHORIA DA FRUTIFICAÇÃO EM VITIS VINIFERA L. CV. \\ 'CARMÉNÈRE' ATRAVÉS DE DIFERENTES BIOESTIMULANTES FOLIARES EM DOIS LOCAIS \\ DIFERENTES
}

\author{
Gastón Gutiérrez-Gamboa ${ }^{1}$, Teresa Garde-Cerdán ${ }^{2}$, Bianca Souza-Da Costa ${ }^{2}$, Yerko Moreno-Simunovic ${ }^{1, *}$ \\ ${ }^{1}$ Centro Tecnológico de la Vid y el Vino, Facultad de Ciencias Agrarias, Universidad de Talca, Av. Lircay S/N, Talca, Chile. \\ ${ }^{2}$ Instituto de Ciencias de la Vid y del Vino (Gobierno de La Rioja-CSIC-Universidad de La Rioja). Carretera de Burgos Km. 6 (Autovía LO-20, \\ salida 13). Finca La Grajera. 26007 Logroño, Spain.
}

*corresponding author: Tel: +56982599138,e-mail: ymoreno@utalca.cl

(Received 30.05.2018. Accepted 28.11.2018)

\section{SUMMARY}

'Carménère' is an important grapevine variety cultivated in Chile, which exhibits a high tendency to fruitlet abscission and "millerandage", reproductive disorders that seriously affect plant productivity. However, despite the existence of a lot of information about the effects of micronutrients on millerandage, few studies exist about the impacts of seaweed biostimulation on reproductive disorders in grapevines, which currently has been classified as elicitor. For these reasons, the aim of this work was to study the effect of different biostimulant applications to 'Carménère' grapevines on fruit set and cluster characteristics during 2011-2012 season. Viticultural parameters such as number and weight of berries, cluster weight, berry size and its distribution along the cluster were measured. In addition, physicochemical parameters in musts from the obtained grapevines were analyzed. The results showed that the treatments based on boron ethanolamine plus zinc oxide and brown algae (Ascophyllum nodosum) improved fruit set in 'Carménère' grapevines in both climate locations, mainly in the colder climate site. Different parameters such as weight and number of berries per bunch, among others, were improved after the application of this treatment. Therefore, the results suggest that it is possible to improve fruit set in 'Carménère' grapevines using a treatment based on certain microelements, such as boron and zinc, and an extract produced from seaweed algae.

\section{RESUMO}

'Carménère' é uma importante casta cultivada no Chile, que apresenta uma alta tendência para distúrbios reprodutivos durante a frutificação, como a abscisão dos bagos e a bagoinha, que afetam seriamente a produtividade da planta. Há muita informação sobre os efeitos dos micronutrientes nos distúrbios reprodutivos. Porém, existem poucos relatos sobre o impacto da bioestimulação a partir do uso de extratos de algas, que têm sido classificados como molécula elicitora, sobre a frutificação da videira. Por estas razões, o objetivo deste trabalho foi estudar o efeito da aplicação de diferentes bioestimulantes em videiras da casta 'Carménère' sobre os bagos e características do cacho durante o ciclo $2011-2012$. Parâmetros vitícolas como o número e peso dos bagos, o peso do cacho, o tamanho do bago e sua distribuição no cacho foram medidos. Além disso, foram analisados alguns parâmetros físico-químicos em mostos. Os resultados mostraram que os tratamentos baseados na aplicação de etanolamina de boro, acrescido de óxido de zinco e algas castanhas (Ascophyllum nodosum) melhoraram a produção de frutos em videiras da casta 'Carménère' no local de clima frio. O valor de parâmetros como o peso e o número de bagos por cachos, entre outros, foi melhorado após a aplicação deste tratamento. Os resultados sugerem que, por vezes, é possível melhorar a produção de videiras da casta 'Carménère' usando um tratamento baseado em microelementos, como o boro e o zinco, e um extrato produzido a partir de algas marinhas.

Key words: Ascophylum nodosum, biostimulation, 'Carménère' grapevines, fruit set, micronutrients, millerandage.

Palavras-chave: Ascophyllum nodosum, bioestimulação, videiras 'Carménère’, frutificação, micronutrientes, bagoinha.

This is an Open Access article distributed under the terms of the Creative Commons Attribution License (http://creativecommons.org/licenses/by/4.0), which permits unrestricted use, distribution, and reproduction in any medium, provided the original work is properly cited. 


\section{INTRODUCTION}

'Carménère' (Vitis vinifera. L) is one of the most widely cultivated grapevine varieties in Chile since its arrival from Bordeaux, France around the year 1851, before the phylloxera (Daktulosphaira vitifoliae) devastation of European grapevines. It is nowadays an important part of the Chilean wine industry (Hernández, 2000). According to the report of the Servicio Agrícola y Ganadero (SAG, 2015), 'Carménère' accounts for 10,503 hectares, reaching a $7.65 \%$ of the national average surface. Currently, this variety is recognized as emblematic in Chile due to its economic importance and international recognition (Pszczólkowsky, 2008). 'Carménère', with a long maturation period, was rediscovered in Chile around 1994, through ampelographic analysis, where it had been misidentified as 'Merlot' or 'Cabernet Franc' (Pszczólkowsky, 2004). The presence of herbaceous and "green" aromas in 'Carménère' wines is mainly due to the synthesis of high concentrations of methoxypyrazines in grapes compared to 'Cabernet Sauvignon' grapevines, strongly related with the climatic conditions of the vineyard (Belancic and Agosin, 2007).

One of the most important problems in 'Carménère' vineyard management is the exhibition of a high tendency to fruitlet abscission and "millerandage", reproductive disorders that seriously affect these traits (Alva et al., 2015). This variety presents flowers with curved filaments, which limit the fruit set and production. In addition 'Carménère' is characterized by late entering into production and by very low yields due to the low fertility of the basal buds (Pszczólkowsky, 2008). Millerandage is characterized by the presence of normal size seeded berries together with with small-size $(<3 \mathrm{~mm})$ and mid-size $(3-6 \mathrm{~mm})$ seedless berries in the same bunch (Alva et al., 2015). Small seedless berries are presumably generated from defective, non-fertile ovules, mid-size seedless berries arise from a parthenocarpic event caused by a defective ovule fertilization due to a failure in pollen tube growth and a sperm cells release into ovaries (Keller, 2010; Alva et al., 2015).

These physiological problems are commonly associated with deficiencies in essential micronutrients such as boron and zinc (Vasconcelos et al., 2009). Boron deficiency is related to the aforementioned physiological problems negatively affecting pollen tube development, pollen germination, pollen tube growth, fruit set and seed formation (Tanaka and Fujiwara, 2008), whereas zinc is required as cofactor in several types of enzymes involved mainly in cell division, nucleic acid metabolism and protein synthesis. Zinc assimilation by grapevines depends on ripening stage of berry, independent of the use of rootstocks (Volschenk et al., 1999). Additionally, biostimulation through seaweed mainly by the Ascophyllum nodosum brown algae has allowed improving grapevine production and phenolics compounds in grapes, being classified by several authors as an elicitor (Khan et al., 2012; Frioni et al., 2018; Gutiérrez-Gamboa et al., 2018). Based on the aforementioned, the aim of this work was to study different strategies to improve fruit set in Vitis vinifera. L cv. 'Carménère' through foliar biostimulation of a different combination of microelements and the use of Ascophyllum nodosum extracts in Maule and BíoBío Valleys.

\section{MATERIAL AND METHODS}

\section{Experimental site and plant material}

The field study was conducted in two commercial vineyards cv. 'Carménère' during 2011-2012. One of the vineyards was located at San Javier, Maule Valley. The vineyard was planted in 2000 with a distance of $2.5 \mathrm{~m}$ between rows and $1.5 \mathrm{~m}$ between plants, accounting for a total of 2,666 vines/ha. The grapevines were trained to a vertically shoot positioned system, leaving around of 28-30 buds per vine. The vineyard has drip irrigation, with an output per plant of $4 \mathrm{~L} / \mathrm{hr}$. The soil is clay loam, and the climate is Mediterranean type with a prolonged dry season during summer. Maximum temperature during the warmest month (January) was $30.1{ }^{\circ} \mathrm{C}$. Accumulated rainfall from September to April was around $84.8 \mathrm{~mm}$. Annual precipitation reached around of $870 \mathrm{~mm}$. The other vineyard was located at Yumbel, BíoBío Valley. The vineyard was planted in 1999 with a distance of $3.0 \mathrm{~m}$ between rows and 1.5 $\mathrm{m}$ between plants accounting for a total of 2,222 vines/ha. The grapevines were trained to a vertically Scott Henry system, leaving around of 58-60 buds per vine. The vineyard has drip irrigation, with an output per plant of $4 \mathrm{~L} / \mathrm{hr}$. The soil is silty loam, and the climate is sub-humid Mediterranean type. Maximum temperature during the warmest month was $28.0^{\circ} \mathrm{C}$. Accumulated rainfall from September to April was around $161.7 \mathrm{~mm}$. Annual precipitation reached around of 1,150 $\mathrm{mm}$. The vineyards were managed under conventional soil tillage management system and were irrigated when the midday leaf water potential $(\psi \mathrm{l})$ reached 1.0 to $1.2 \mathrm{MPa}$. Respect to the nutritional management of the vineyards, $2 \mathrm{~kg}$ of nitrogen and $3 \mathrm{~kg}$ of potassium per ton of harvested fruit were partially applied. 


\section{Grapevine treatments}

Five treatments were applied to the grapevines as well as control. Three commercial biostimulants were applied to the grapevines. The first, a product based on the Ascophyllum nodosum seaweed combined with boron and zinc (BM86, Goëmar, Saint -Malo, France). The second, a product based on boron ethanolamine and zinc oxide (Zintrac $700+$ Bortrac 150, Yara, Oslo, Norwey). The third, a product based on molybdenum (Molitrac, Yara, Oslo, Norwey). A mixture of BM86 and Zintrac $700+$ Bortrac 150 and sugar at $2 \% \mathrm{v} / \mathrm{v}$ were also applied to the vineyards. Treatments were applied with a back sprayer in different phenological growth stages depending on the recommendations of the product, with a wetting of $667 \mathrm{~L} / \mathrm{ha}$. Treatments were performed in triplicate and were distributed as a complete randomized block design. Each replication had 16 grapevines, and therefore a total of 48 plants were used in each treatment, leaving 10 untreated plants in the same row and two rows between replicates to avoid treatment contamination. Treatments consisted of applying the recommended amount of the product, divided in two or three moments, the first at seven days after flowering, the second ten days after the first application (flowering) and the third, at ten days after the second application. Additionally, 48 grapevines, distributed in the same way, were kept untreated (Control). Composition and content of the products are shown in Table I.

TABLE I

Composition, concentration, level and time of application of the treatments

Composição, concentração, dose e época de aplicação dos tratamentos

\begin{tabular}{ccccc}
\hline Treatment & Commercial product & Active ingredient & Dose & Time of application \\
\hline T1 & Untreated & Water & 1) Seven days after beginning of \\
flowering. 2) Flowering. 3) Ten days after \\
the second application.
\end{tabular}

\section{Sample evaluations}

Ten clusters by grapevine were harvested when the grape berries reached pea grain size, and different parameters such as weight of clusters, number of fruit set berries and distribution of berries by weight and caliber along the clusters were evaluated. The rest of the clusters were collected at harvest stage and these same measurements were performed together with the analysis of technological maturity $\left({ }^{\circ} \mathrm{Brix}, \mathrm{pH}\right.$ and total acidity), according to the methodology described by the OIV (2003). Weight of clusters was performed using an analytical balance (Cubis ${ }^{\circledR}$ Precision Balance, Sartorius, Göttingen, Germany). Distribution and weight of grape berries by size was measured using a sieve with three different levels, after separation of all berries from the bunch. Separation by size had three ranges: the first from 16 to $12 \mathrm{~mm}$ (as large diameter), the second from 12 to $8 \mathrm{~mm}$ (as medium diameter) and the third from 8 to $4 \mathrm{~mm}$ (as small diameter). Subsequently, weight of the obtained berries of each range was measured using an analytical scale (Cubis ${ }^{\circledR}$ Precision Balance, Sartorius, Göttingen, Germany).

\section{Statistical analysis}

The statistical analysis in relation to the analyzed parameters was performed using variance analysis (ANOVA), by Statgraphics Centurion XVI.I (Warrento, Virginia, United States). Differences between samples were compared using the Duncan test at $95 \%$ confidence level.

\section{RESULTS AND DISCUSSION}

Effects of micronutrients and bioestimulant applications to 'Carménère' grapevines at pea sized stage 
First evaluations were made at pea size stage with the aim to determine if the treatments allowed improving bloom and fruit set in 'Carménère' grapevines. No significant differences were found between the evaluated parameters, after micronutrients and bioestimulants applications to the 'Carménère' grapevines in the warm climate (Maule Valley) and the control plants (Table 2). However, the number of small berries ( 8 to $4 \mathrm{~mm}$ ) was higher in untreated (control) and treated with sugar (T6) grapevines (Table II). These differences may be attributed to a yield compensation effect observed early in ripening since the number of berries of medium diameter $(12$ to $8 \mathrm{~mm}$ ) was higher in untreated and treated with T6, although without significant differences. Micronutrients and bioestimulants applications to the 'Carménère' grapevines in the cold climate (BíoBío Valley) affected weight of cluster, number of berries per cluster, number and weight of berries of medium diameter (Table III). These parameters were higher in grapes treated with BM 86 (T2) and Zintrac $700+$ Bortract 150 (T3) than in the grapes from untreated grapevines and treated with Molitrac (T5) and Sugar (T6), with the exception of weight of berries of medium diameter (Table III). Samples treated with a combination of $\mathrm{T} 2+\mathrm{T} 3$ presented higher number of berries per cluster and weight of berries of medium diameter than the grapes from untreated grapevines (Table 3). Based on these results, micronutrients such as boron and zinc and the extract of Ascophyllum nodosum allowed to improve fruit set in the grapevines planted in the cold site (BíoBío Valley). Boron ethanolamine is sold a fertilizer which is quickly absorbed by plant tissues, stimulating growth of cambium tissues and apical meristems, promoting calcium mobility and the production of pollen and bloom fertility (Brown and Shelp, 1997; Arrington and DeVetter, 2017). Reproductive tissues of vines are most susceptible to boron deficiency, which results in reduced fruit-set, small "shot berries" that are around to pumpkin-shaped, and flower and fruit cluster necrosis (Christensen et al., 2006). Deficiencies in boron are also associated with higher rainfall areas and irrigated soils (Christensen et al., 2006). On the other hand, zinc is involved in berry development, the synthesis of growth regulators and chlorophyll (Volschenk et al., 1999). Based on our results, it was observed that biostimulation was more effective in the vineyard planted in BíoBío Valley, where the climatic conditions were colder and a greater amount of rainfall falls. On the other hand, different results have been reported by certain authors in respect to the effects of boron applications to some plant crops. Biostimulation through boron / zinc applications improved seed set, seed yield and seed quality in Alfalfa (Medicago sativa L.), number, length and weight of berries, length and weight of clusters, and number and size of seeds in grapevines (Vitis vinifera L.), whereas it did not increase fruit set or yield in Northern Highbush Blueberry (Vaccinium corymbosum) plants (Dordas, 2005; Nikkhah et al., 2013; Arrington and DeVetter, 2017). Besides, foliar applications of seaweed extracts from Ascophyllum nodosum improved growth and physicochemical parameters in grape berries (Khan et al., 2012).

\section{TABLE II}

Viticultural parameters after biostimulation at pea-sized stage in 'Carménère' grapevines growing in a warm climate (Maule Valley)

Parâmetros vitícolas após bioestimulação, ao bago de ervilha, em vinhas 'Carménère’ em clima quente (Vale do Maule)

\begin{tabular}{|c|c|c|c|c|c|c|c|c|}
\hline & $\begin{array}{l}\text { Weight of } \\
\text { bunch }^{\mathrm{a}}\end{array}$ & $\begin{array}{c}\text { Number } \\
\text { of berries } \\
\text { / bunch }\end{array}$ & $\begin{array}{l}\text { Number of } \\
\text { berries of } \\
16-12 \mathrm{~mm}\end{array}$ & $\begin{array}{c}\text { Number of } \\
\text { berries of } \\
12-8 \mathrm{~mm}\end{array}$ & $\begin{array}{l}\text { Number } \\
\text { of berries } \\
\text { of } 8-4 \mathrm{~mm}\end{array}$ & $\begin{array}{l}\text { Weight of } \\
\text { berries of } \\
16-12 \mathrm{~mm}\end{array}$ & $\begin{array}{c}\text { Weight of } \\
\text { berries of } \\
12-8 \mathrm{~mm}\end{array}$ & $\begin{array}{c}\text { Weight of } \\
\text { berries of } \\
8-4 \mathrm{~mm}\end{array}$ \\
\hline Control (T1) & 52.4 & 98.7 & 15 & 55.9 & $31.3 \mathrm{~b}$ & 15.2 & 27.9 & 6.3 \\
\hline BM 86 (T2) & 59.0 & 87.7 & 23.2 & 48.7 & $16.9 \mathrm{a}$ & 25.8 & 27.6 & 2.4 \\
\hline $\begin{array}{l}\text { Zintrac } 700+\text { Bortrac } \\
150 \text { (T3) }\end{array}$ & 63.6 & 92.5 & 24.3 & 53.5 & $17.3 \mathrm{a}$ & 25 & 31.6 & 2.7 \\
\hline $\mathrm{T} 2+\mathrm{T} 3(\mathrm{~T} 4)$ & 73.7 & 92.5 & 17.5 & 47.5 & $20.0 \mathrm{ab}$ & 23.7 & 30.9 & 4.2 \\
\hline Molitrac (T5) & 49.7 & 92.9 & 17.8 & 45.6 & $27.9 \mathrm{ab}$ & 19.3 & 23.5 & 3.6 \\
\hline Sugar (T6) & 53.4 & 108.9 & 17 & 57.5 & $35.3 b$ & 17 & 28.7 & 4.3 \\
\hline $\begin{array}{l}\text { Coefficient of variation } \\
(\%)\end{array}$ & 13.9 & 9.8 & 19.5 & 9.4 & 28.7 & 20.5 & 10.7 & 40.7 \\
\hline Significance & ns & ns & ns & ns & $*$ & ns & ns & ns \\
\hline
\end{tabular}


TABLE III

Viticultural parameters after biostimulation at pea-sized stage in 'Carménère' grapevines growing in a cold climate (BíoBío Valley)

Parâmetros vitícolas após bioestimulação, ao bago de ervilha, em vinhas 'Carménère’ em clima frio (Vale do BíoBío)

\begin{tabular}{|c|c|c|c|c|c|c|c|c|}
\hline & $\begin{array}{l}\text { Weight of } \\
\text { bunch }^{\mathrm{a}}\end{array}$ & $\begin{array}{c}\text { Number } \\
\text { of berries } \\
\text { / bunch }\end{array}$ & $\begin{array}{l}\text { Number of } \\
\text { berries of } \\
16-12 \mathrm{~mm}\end{array}$ & $\begin{array}{c}\text { Number of } \\
\text { berries of } \\
12-8 \mathrm{~mm}\end{array}$ & $\begin{array}{l}\text { Number of } \\
\text { berries of } \\
8-4 \mathrm{~mm}\end{array}$ & $\begin{array}{l}\text { Weight }{ }^{\mathrm{a}} \text { of } \\
\text { berries of } \\
16-12 \mathrm{~mm}\end{array}$ & $\begin{array}{l}\text { Weight }{ }^{\mathrm{a}} \text { of } \\
\text { berries of } \\
12-8 \mathrm{~mm}\end{array}$ & $\begin{array}{c}\text { Weight }{ }^{\mathrm{a}} \text { of } \\
\text { berries of } \\
8-4 \mathrm{~mm}\end{array}$ \\
\hline Control (T1) & $51.8 \mathrm{a}$ & $108.4 \mathrm{a}$ & 1.4 & $81.8 \mathrm{a}$ & 26.8 & 1.6 & $40.2 \mathrm{a}$ & 3.9 \\
\hline $\begin{array}{l}\text { BM } 86(\mathrm{~T} 2) \\
\text { Zintrac } 700+\text { Bortrac }\end{array}$ & $77.0 \mathrm{~b}$ & $159.0 \mathrm{c}$ & 1.8 & $122.9 \mathrm{c}$ & 34.4 & 2.3 & $64.2 \mathrm{c}$ & 4.9 \\
\hline $150(\mathrm{~T} 3)$ & $77.3 b$ & $156.0 \mathrm{c}$ & 1.3 & $119.8 \mathrm{bc}$ & 34.5 & 2.1 & $64.0 \mathrm{c}$ & 4.8 \\
\hline $\begin{array}{l}\mathrm{T} 2+\mathrm{T} 3(\mathrm{~T} 4) \\
\text { Molitrac (T5) }\end{array}$ & $\begin{array}{c}65.8 \mathrm{ab} \\
63.9 \mathrm{a}\end{array}$ & $\begin{array}{l}141.9 \mathrm{bc} \\
128.4 \mathrm{ab}\end{array}$ & $\begin{array}{c}1.4 \\
2\end{array}$ & $\begin{array}{c}100.9 \mathrm{ab} \\
95.4 \mathrm{a}\end{array}$ & $\begin{array}{l}39.6 \\
29.9\end{array}$ & $\begin{array}{l}1.7 \\
2.2\end{array}$ & $\begin{array}{l}55.1 \mathrm{bc} \\
52.5 \mathrm{bc}\end{array}$ & $\begin{array}{l}5.1 \\
5.2\end{array}$ \\
\hline $\begin{array}{l}\text { Sugar (T6) } \\
\text { Coefficient of variation } \\
(\%)\end{array}$ & $\begin{array}{c}55.8 \mathrm{a} \\
16\end{array}$ & $\begin{array}{c}117.0 \mathrm{ab} \\
15.3\end{array}$ & $\begin{array}{l}0.6 \\
34.1\end{array}$ & $\begin{array}{c}89.8 \mathrm{a} \\
16.2\end{array}$ & $\begin{array}{l}28.5 \\
14.7\end{array}$ & $\begin{array}{l}0.8 \\
36.7\end{array}$ & $\begin{array}{c}45.6 \mathrm{ab} \\
17.8\end{array}$ & $\begin{array}{l}4.1 \\
12.5\end{array}$ \\
\hline Significance & $*$ & $*$ & NS & * & ns & ns & * & ns \\
\hline
\end{tabular}

Effects of micronutrients and bioestimulants applications to 'Carménère' grapevines at harvest

Evaluations were also performed at harvest, since it is possible that bloom and fruit set is normally developed. However, at the beginning of fruit growth, the "millerandage" phenomenon may be developed and grape bunches may contain berries that differ greatly in size and maturity. Besides, it has been reported that cool conditions during bloom caused a greater occurrence of "millerandage" (Neethling et al., 2017).
In the warm site (Maule Valley) Foliar applications of the treatments to 'Carménère' grapevines affected the number of berries per bunch and the number of berries of minimum diameter (Table 4). Grapes harvested from grapevines treated with Zintrac $700+$ Bortrac 150 (T3) presented higher number of berries per bunch than grapes from grapevines untreated and treated with BM $86+$ Zintrac $700+$ Bortrac 150 (T4), Molitract (T5) and sugar (T6) (Table 4). Moreover, all the treatments increased the number of small berries compared to untreated plants (Table IV).

TABLE IV

Viticultural parameters after biostimulation at harvest in 'Carménère' grapevines growing in a warm climate (Maule Valley)

Parâmetros vitícolas após bioestimulação, à colheita, em videiras 'Carménère’ produzidas em clima quente (Vale do Maule)

\begin{tabular}{|c|c|c|c|c|c|c|c|c|}
\hline & $\begin{array}{l}\text { Weight of } \\
\text { bunch }^{\mathrm{a}}\end{array}$ & $\begin{array}{l}\text { Number } \\
\text { of berries } \\
\text { / bunch }\end{array}$ & $\begin{array}{l}\text { Number of } \\
\text { berries of } \\
16-12 \mathrm{~mm}\end{array}$ & $\begin{array}{c}\text { Number of } \\
\text { berries of } \\
12-8 \mathrm{~mm}\end{array}$ & $\begin{array}{c}\text { Number } \\
\text { of berries } \\
\text { of 8-4 mm }\end{array}$ & $\begin{array}{l}\text { Weight }{ }^{\mathrm{a}} \text { of } \\
\text { berries of } \\
16-12 \mathrm{~mm}\end{array}$ & $\begin{array}{l}\text { Weight }{ }^{\mathrm{a}} \text { of } \\
\text { berries of } \\
12-8 \mathrm{~mm}\end{array}$ & $\begin{array}{c}\text { Weight }{ }^{\mathrm{a}} \text { of } \\
\text { berries of 8-4 } \\
\text { mm }\end{array}$ \\
\hline Control (T1) & 91.8 & $78.7 \mathrm{a}$ & 37.7 & 23.6 & $16.8 \mathrm{a}$ & 65.5 & 17.1 & 2.7 \\
\hline BM 86 (T2) & 102.9 & $92.9 \mathrm{ab}$ & 46.9 & 32.3 & $49.9 \mathrm{bc}$ & 73 & 23 & 2.1 \\
\hline $\begin{array}{l}\text { Zintrac } 700+\text { Bortrac } \\
150 \text { (T3) }\end{array}$ & 102.3 & $106.8 \mathrm{~b}$ & 47.8 & 24.7 & $50.9 \mathrm{c}$ & 75.2 & 20.3 & 3.3 \\
\hline $\mathrm{T} 2+\mathrm{T} 3(\mathrm{~T} 4)$ & 96.5 & $88.1 \mathrm{a}$ & 43 & 27 & $41.8 \mathrm{bc}$ & 72.3 & 17.1 & 2.6 \\
\hline Molitrac (T5) & 93.5 & $87.2 \mathrm{a}$ & 40.6 & 28.2 & $37.9 \mathrm{~b}$ & 67.9 & 18.1 & 2.8 \\
\hline Sugar (T6) & 85.5 & $84.0 \mathrm{a}$ & 42.2 & 13.9 & $38.6 b$ & 71.2 & 18.6 & 3.2 \\
\hline $\begin{array}{l}\text { Coefficient of } \\
\text { variation }(\%)\end{array}$ & 6.1 & 10.8 & 8.9 & 13.9 & 31.1 & 6.9 & 15 & 18.1 \\
\hline Significance & $\mathrm{ns}$ & $*$ & $\mathrm{~ns}$ & ns & $*$ & $\mathrm{~ns}$ & $\mathrm{~ns}$ & ns \\
\hline
\end{tabular}

In the cold climate (BioBio Valley), treatments applied to the grapevines affected all viticultural parameters, except the number and weight of the berries of medium and small diameter (Table V). Grapes from grapevines treated with $\mathrm{T} 3$ presented the highest weight of cluster and number of berries per 
bunch. In addition, these grapes presented the highest number and weight of berries of large diameter. The same happened with grapes from grapevines treated with T2. Due to the aforementioned, it is possible that the effectiveness of biostimulation, mainly through boron plus zinc treatment was higher at harvest than at pea size phase, when the phloem and gas exchange is less active. Brown et al. (1999) reported that boron mobility is due to the production of sugar alcohols, enabling the cotransport of boron-polyol complexes in the phloem. Keller et al. (2014) indicated that the decrease in xylem inflow at the onset of ripening may be a consequence of the sink-driven increase in phloem inflow.

\section{TABLE V}

Viticultural parameters after biostimulation at harvest in 'Carménère' grapevines growing in a cold climate (BíoBío Valley)

Parâmetros vitícolas após bioestimulação, à colheita, em videiras 'Carménère’ produzidas em clima frio (Vale do BíoBío)

\begin{tabular}{|c|c|c|c|c|c|c|c|c|}
\hline & $\begin{array}{l}\text { Weight of } \\
\text { bunch }^{\mathrm{a}}\end{array}$ & $\begin{array}{l}\text { Number } \\
\text { of berries } \\
\text { / bunch }\end{array}$ & $\begin{array}{l}\text { Number of } \\
\text { berries of } \\
16-12 \mathrm{~mm}\end{array}$ & $\begin{array}{c}\text { Number of } \\
\text { berries of } \\
12-8 \mathrm{~mm}\end{array}$ & $\begin{array}{c}\text { Number } \\
\text { of berries } \\
\text { of } 8-4 \mathrm{~mm}\end{array}$ & $\begin{array}{l}\text { Weight }{ }^{\mathrm{a}} \text { of } \\
\text { berries of } \\
16-12 \mathrm{~mm}\end{array}$ & $\begin{array}{l}\text { Weight }{ }^{\mathrm{a}} \text { of } \\
\text { berries of } \\
12-8 \mathrm{~mm}\end{array}$ & $\begin{array}{c}\text { Weight }{ }^{\mathrm{a}} \text { of } \\
\text { berries of } \\
8-4 \mathrm{~mm}\end{array}$ \\
\hline Control (T1) & $110.0 \mathrm{a}$ & $106.9 \mathrm{a}$ & $53.6 \mathrm{a}$ & 42.8 & 14.3 & $75.0 \mathrm{a}$ & 27.4 & 2.8 \\
\hline BM 86 (T2) & $130.8 b$ & $127.0 \mathrm{~b}$ & $65.2 \mathrm{ab}$ & 44.9 & 18.5 & $94.3 b c$ & 29.5 & 2.2 \\
\hline $\begin{array}{l}\text { Zintrac } 700+\text { Bortrac } \\
150(\mathrm{~T} 3)\end{array}$ & $150.0 \mathrm{c}$ & $149.3 \mathrm{c}$ & $76.7 b$ & 44.4 & 14.5 & $112.8 \mathrm{c}$ & 31 & 2.4 \\
\hline $\mathrm{T} 2+\mathrm{T} 3(\mathrm{~T} 4)$ & $120.8 \mathrm{ab}$ & $117.3 \mathrm{ab}$ & $59.1 \mathrm{a}$ & 43.3 & 16.8 & $85.1 \mathrm{ab}$ & 28.5 & 3 \\
\hline Molitrac (T5) & $115.0 \mathrm{ab}$ & $111.3 \mathrm{ab}$ & $56.9 \mathrm{a}$ & 38.4 & 17.4 & $82.3 \mathrm{ab}$ & 26 & 3 \\
\hline Sugar (T6) & $106.4 \mathrm{a}$ & $103.6 \mathrm{a}$ & $56.8 \mathrm{a}$ & 32.1 & 7.4 & $78.5 \mathrm{ab}$ & 22.3 & 1.4 \\
\hline $\begin{array}{l}\text { Coefficient of variation } \\
(\%)\end{array}$ & 13.4 & 14.2 & 13.7 & 12 & 26.9 & 16.2 & 12.1 & 24.7 \\
\hline Significance & $*$ & $*$ & $*$ & ns & ns & $*$ & ns & ns \\
\hline
\end{tabular}

\section{Oenological parameters}

According to Table VI, none of the must oenological parameters measured was affected by the biostimulation through the different foliar applications. These results are similar to those reported by several authors (Gutiérrez-Gamboa et al., 2017a, Gutiérrez-Gamboa et al., 2017b, Frioni et al., 2018), who showed little effects of biostimulation through nitrogen fertilizers, algae extracts, among others, on must oenological parameters. Contrary to these results, Khan et al. (2012) showed that the application of Ascophyllum nodosum extracts application to the grapevines improved soluble solids, titratable acidity, $\mathrm{pH}$, total sugars, reducing sugars and ascorbic acid as compared to unsprayed grapevines.

TABLE VI

Must oenological parameters from untreated and treated grapevines

Parâmetros enológicos obtidos em videiras não tratadas e tratadas

\begin{tabular}{|c|c|c|c|c|c|c|}
\hline & \multicolumn{3}{|c|}{ Maule Valley } & \multicolumn{3}{|c|}{ BíoBío Valley } \\
\hline & $\begin{array}{c}\text { Soluble } \\
\text { solids }\left({ }^{\circ} \text { Brix }\right)\end{array}$ & $\begin{array}{c}\text { Total acidity } \\
(\mathrm{g} / \mathrm{L})\end{array}$ & $\mathbf{p H}$ & $\begin{array}{c}\text { Soluble solids } \\
\text { ( }{ }^{\circ} \text { Brix) }\end{array}$ & $\begin{array}{c}\text { Total acidity } \\
(\mathrm{g} / \mathrm{L})\end{array}$ & pH \\
\hline Control (T1) & 25.2 & 4.08 & 3.3 & 25.6 & 4.38 & 3.8 \\
\hline BM 86 (T2) & 25.6 & 3.8 & 3.4 & 25.6 & 4.81 & 3.6 \\
\hline Zintrac $700+$ Bortrac $150(\mathrm{~T} 3)$ & 23.4 & 4.6 & 3.2 & 25.2 & 5.2 & 3.5 \\
\hline $\mathrm{T} 2+\mathrm{T} 3(\mathrm{~T} 4)$ & 23 & 4.1 & 3.3 & 24.8 & 4.62 & 3.8 \\
\hline Molitrac (T5) & 23.2 & 4.1 & 3.4 & 26.2 & 4.7 & 3.7 \\
\hline Sugar (T6) & 23.6 & 4.03 & 3.4 & 24.5 & 4.73 & 3.7 \\
\hline Significance & ns & ns & $\mathrm{ns}$ & ns & ns & ns \\
\hline
\end{tabular}




\section{CONCLUSIONS}

These preliminary results suggest that a combination of boron plus zinc can improved the fruit set levels on 'Carménère' bunches, compared with others treatments in the cold climate site. Biostimulation through seeweed brown algae Ascophyllum nodosum extract can allow an improvement of fruit set only when compared to untreated grapevines. On the contrary, molybdenum applications to the grapevines did not affect fruit set in 'Carménère' grapevines. The vineyard planted in the cold climate site presented a

\section{REFERENCES}

Alva O., Roa-Roco R.N., Pérez-Díaz R., Yáñez M., Tapia J., Moreno Y., Ruiz-Lara S., González E., 2015. Pollen morphology and boron concentration in floral tissues as factors triggering natural and GA-induced parthenocarpic fruit development in grapevine. PLOS ONE, 10: 0139503.

Arrington M., DeVetter L.W., 2017. Foliar applications of calcium and boron do not increase fruit set or yield in Northern Highbush Blueberry (Vaccinium corymbosum). HortScience, 52, 1259-1264.

Belancic A., Agosin E., 2007. Methoxypyrazines in grapes and wines of Vitis vinifera cv. Carmenere. Am. J. Enol. Vitic, 58, 462469.

Brown P.H., Hu H., Roberts W.G., 1999. Occurrence of sugar alcohols determines boron toxicity symptom of ornamental species. HortScience, 124, 347-352.

Brown P.H., Shelp B.J., 1997. Boron mobility in plants. Plant Soil, 193, 85-101.

Christensen L.P., Beede R.H., Peacock W.L., 2006. Fall foliar sprays prevent boron-deficiency symptoms in grapes. Calif. Agric, 60, 100-103.

Dordas C., 2005. Foliar boron application improves seed set, seed yield, and seed quality of Alfalfa. Agron. J, 98, 907-913.

Frioni T., Sabbatini P., Tombesi S., Norrie J., Poni S., Gatti M., Pallioti A., 2018. Effects of a biostimulant derived from the brown seaweed Ascophyllum nodosum on ripening dynamics and fruit quality of grapevines. Sci. Hort., 232. 97-106.

Gutiérrez-Gamboa G., Garde-Cerdán T., Gonzalo-Diago A., Moreno-Simunovic Y., Martínez-Gil, AM., 2017a. Effect of different foliar nitrogen applications on the must amino acids and glutathione composition in Cabernet Sauvignon vineyard. LWTFood Sci. Technol, 75, 147-154.

Gutiérrez-Gamboa G., Portu J., Santamaría P., López R., GardeCerdán T., 2017b. Effects on grape amino acid concentration through foliar application of three different elicitors. Food Res. Int. 99, 688-692.

Gutiérrez-Gamboa G., Romanazzi G., Garde-Cerdán T., PérezÁlvarez E.P., 2018. A review of the use of biostimulants in the vineyard for improved grape and wine quality: Effects on prevention of grapevine diseases. J. Sci. Food Agric. In Press. higher number of small berries than on the warm site and the boron and zinc applications improved this parameter compared to untreated grapevines. Based on these preliminary results, boron plus zinc and brown algae applications before the beginning of flowering can allow to improve fruit set, which would affect positively 'Carménère' productivity at harvest. However, evaluations during more seasons must be carried out to the vineyard in order to better understand the effects of biostimulations of microelements and seaweeds to 'Carménère' grapevines on fruit set.

Hernández A., 2000. Introducción al vino de Chile. Santiago, Chile: Ediciones Universidad Católica de Chile.

Keller M., 2010. The Science of Grapevines: Anatomy and Physiology. London: Academic Press.

Keller M., Zhang Y., Shrestha P.M., Biondi M., Bondada B.R., 2014. Sugar demand of ripening grape berries leads to recycling of surplus phloem water via the xylem. Pant Cell Environ., 38, 10481059.

Khan A.S., Ahmad B., Jaskani MJ., Ahmad R., Malik A.U., 2012. Foliar application of mixture of amino acids and seaweed (Ascophylum nodosum) extract improve growth and physicochemical properties of grapes. Int. J. Agric. Biol., 14, 383388 .

Neethling E., Petitjean T., Quénol H., Barbeau G., 2017. Assessing local climate vulnerability and winegrowers' adaptive processes in the context of climate change. Mitig. Adap. Strat. Gl, 22, 777-803.

Nikkhah R., Nafar H., Rastgoo S., Dorostkar M., 2013. Effect of foliar application of boron and zinc on qualitative and quantitative fruit characteristics of grapevine (Vitis vinifera L.). Int. J. Agric. Crop Sci., 6, 485-492.

OIV, 2003. Compendium of internationals methods of wine and must analysis. Paris: OIV.

Pszczólkowsky P., 2004. Les millésimes: Chili 2004. Académie Suisse du Vin, 42, 9-10.

Pszczólkowsky P., 2008. La culture du cépage Carmenere: L'optimum pour la qualité de son vin. Progrès Agricole et Viticole, 9, 125 .

SAG, 2015. Catastro Vitícola Nacional. Servicio Agrícola $y$ Ganadero, Santiago, Chile (http://www.sag.gob.cl/).

Tanaka M., Fujiwara T., 2008. Physiological roles and transport mechanisms of boron: perspectives from plants. Eur. J. Physiol., 456, 671-677.

Vasconcelos M., Greven M., Winefield C., Trought M., Raw V., 2009. The flowering process of Vitis vinifera: A review. Am. J. Enol. Vitic., 60, 411-434.

Volschenk C.G., Hunter J.J., Le Roux D.J., Watts J.E., 1999. Effect of graft combination and position of application on assimilation and translocation of zinc in grapevines. J. Plant Nutr., 22, 115-119. 